\title{
在宅パーキンソン病患者の異なる歩行速度と 身体組成および立位バランスとの関連
}

\section{Relationships between different walking speeds and body composition or standing balance in home-care patients with Parkinson's disease}

\author{
村田 伸 ${ }^{1)}$, 兒玉 隆之 ${ }^{1)}$, 中野 英樹1), 相馬 正之 $\dot{2}^{2)}$ \\ 佐藤 洋介 ${ }^{2)}$, 弓岡 まみ ${ }^{3)}$, 村田 潤 ${ }^{4)}$, 中江 秀幸 ${ }^{2)}$
}

Shin Murata, Takayuki Kodama, Hideki Nakano, Masayuki Soma

Yosuke Satou, Mami Yumioka, Jun Murata, Hideyuki Nakae

要旨：本研究の目的は，自力歩行が可能で在宅生活しているパーキンソン病患者 14 名（男 性 6 名, 女性 8 名, 平均年齢71. $3 \pm 6.1$ 歳）を対象に，通常・最速・低速での歩行速度を 測定し，各種バランステストおよび骨格筋量との関連から，パーキンソン病患者の歩行能 力評価に適した歩行速度計測の方法について検証することである。相関分析の結果，通常 歩行速度と有意な相関を示したのは Timed up \& go test（TUG）のみであり，最速歩行 速度のそれは身長，TUG，Functional reach test（FRT）の 3 項目であった。一方，低速 歩行速度と有意な相関を示したのは骨格筋量, 上肢・下肢・体幹筋量の 4 項目であった。 さらに, 最速歩行と低速歩行の速度差と有意な相関を示したのは身長, 骨格筋量, 上肢・ 下肢・体幹筋量，TUG，FRTの７項目に及んだ。これらの知見から，パーキンソン病患 者の歩行能力評価は通常歩行で速度計測するよりも，最速歩行に加えて低速歩行でも評価 する重要性が示された。

キーワード：パーキンソン病患者，低速歩行，立位バランス，身体組成

\begin{abstract}
To determine an appropriate method to measure gait speed in patients with Parkinson's disease (PD), the maximum, normal, and slow gait speeds of $14 \mathrm{PD}$ patients $(6$ males, 8 females, $71.3 \pm 6.1$ years), who were able to walk independently and living at home, were measured, and their relationships with various balance test results and the skeletal muscle volume were analyzed. Normal gait speed was only significantly correlated with the Timed up \& go test (TUG) score, whereas maximum gait speed was significantly correlated with the height, and TUG and Functional reach test (FRT) scores. Slow gait speed was significantly correlated with skeletal, upper/lower limb, and trunk muscle volumes. Furthermore, the difference between the maximum and slow gait speeds was significantly correlated with height, skeletal, upper/lower limb, and trunk muscle volumes, and TUG and FRT scores. The results highlight the importance of assessing gait at low speeds, in addition to maximum speeds, rather than normal speeds, in PD patients.
\end{abstract}

Key words: parkinson's disease, slow gait speed, standing balance, body composition

\footnotetext{
受付日：2019年11月 5 日，採択日：2019年12月10日

京都橘大学健康科学部： $\bar{\top} 607-8175$ 京都市山科区大宅山田34

TEL : 075-571-1111 E-mail : muratas3944@gmail.com

Faculty of Health Science, Kyoto Tachibana University

2) 東北福祉大学健康科学部

Faculty of Health Sciences, Tohoku Fukushi University

3) 大阪人間科学大学人間科学部

Faculty of Human Sciences, Osaka University of Human Sciences

4) 長崎大学大学院医歯薬学総合研究科

Graduate School of Biomedical Sciences, Nagasaki University
} 


\section{I 。背 景}

パーキンソン病の主な症状は安静時振戦, 無動・寡 動, 筋固縮, 姿勢反射障害であり1), 日本における有 病率は人口10万人あたり 100～150人と推定されてい る2)。また，パーキンソン病は進行性の神経難病であ るが, 生命予後は比較的良好で一般の高齢者と大差が ないことが報告3)されている。よってパーキンソン病 患者は, 要介護状態での在宅生活が長く, 地域リハビ リテーションを実践するうえでとくに重要視されてい る

パーキンソン病患者は, 疾患由来による振戦, 筋固 縮, 無動, 姿勢反射障害などの一次的な機能障害が複 合的に出現することで，バランス障害や歩行障害が出 現し, 転倒や骨折を引き起こしやすい。このため, パー キンソン病患者のバランス機能や歩行の評価が繰り返 し報告 ${ }^{5-10)}$ されてきた。パーキンソン病患者のバラン ス評価には, Timed up \& go test(TUG) ${ }^{5)}$, Functional reach test (FRT $)^{6)}$, 重心動摇 ${ }^{7}$ などが報告されてお り, いずれも一般高齢者と比較してパーキンソン病患 者の立位バランスが低下していることが明らかにされ ている。また, パーキンソン病患者の歩行評価につい ては，通常歩行速度 ${ }^{8}$ や や最速歩行速度 ${ }^{10,11)}$ で測定され ることが多く，これらも一般の高齢者と比較すると速 度が遅いことが報告されている。

パーキンソン病患者の歩行機能とバランス機能との 関連について, Paker ら ${ }^{9)}$ は通常歩行速度が速い者ほ どTUG 所要時間が短いことを報告し，高見ら ${ }^{10)}$ は最 速歩行速度が速い者ほど重心動摇の総軌跡長が短いこ とを報告している。一方，八谷ら ${ }^{12)}$ は出来るだけゆっ くり歩く「低速歩行」に着目し, ゆっくり歩けるパー キンソン病患者は足趾把持力が強く, 歩幅を調整でき ることからバランス機能が高いことを示唆している。

ただし，これら先行研究は通常・最速・低速におけ るそれぞれの歩行速度と，一部のバランステストとの 関連を検討したに過ぎず，異なるどの歩行速度がパー キンソン病患者のバランス機能をよく反映するのかに ついては明らかにされていない。そこで本研究は, 自 力歩行が可能で在宅生活しているパーキンソン病患者 を対象に, 通常・最速・低速での歩行速度を測定し, 各種バランステストおよび筋機能をよく反映すること が確認 ${ }^{13)}$ されている身体組成計による骨格筋量との関 連から，パーキンソン病患者の歩行能力評価に適した 歩行速度計測の方法について検証した。

\section{II. 対象と方法}

1. 対 象

対象は, 宮城県パーキンソン病友の会に所属し, 友 の会会報誌に掲載された本研究参加への呼びかけに同 意した在宅パーキンソン病患者16名である。ただし， 16名のうち 2 名が全ての測定を実施できなかったため, 解析対象者は14名となった。14名の内訳は, 男性が 6 名, 女性が 8 名であり, 平均年齢は71. $3 \pm 6.1$ 歳, 平

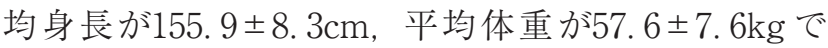
あった。Hoehn \& Yahrの重症度分類は stage II が 5 名, stage IIIが9名であり，発症からの期間は平均 107. $0 \pm 64.5$ 週, 認知機能評価である Mini-mental state examination (MMSE) の平均は27.3 2 2.1点, 最低 点が24点と認知症の疑いがある対象はいなかった。

なお, 対象者には研究の趣旨と内容, 得られたデー 夕は研究の目的以外で使用しないこと，および個人情 報の漏洩に注意することについて説明し，理解を得た 上で協力を求めた。さらに，研究への参加は自由意思 であり，被験者にならなくても不利益にならないこと を口頭と書面で説明し同意を得た。また，本研究実施 にあたり，著者所属大学の研究倫理委員会の承認を得 た（承認番号 $17-33) 。$

\section{2. 方 法}

年齢や性別, Hoehn \& Yahr の重症度分類などの個 人情報を聴取したのち，身長，体重，MMSEを測定 し，歩行速度ならびに身体組成と各種立位バランステ ストを実施した。

歩行パラメータの測定には，アニマ社製のシート式 足圧接地足跡計測器ウォーク Way MW-1000を使用し た。ウォークWayは, ヒトの歩行分析に必要な空間 パラメータ（ストライド長, 歩幅, 歩隔, 歩行角, つ ま先角など）と時間パラメー夕（歩行速度，立脚時間， 両脚支持時間など）について，シート上を歩行するこ とで収集するシステムである。歩行シートのサイズは, 長さ $2400 \mathrm{~mm}$ ，幅 $800 \mathrm{~mm}$ (センサーシート部600mm×600 $\mathrm{mm}$ ，厚さ $5 \mathrm{~mm}$ ) であり，センサー空間分解能は $10 \mathrm{~mm} \times$ $10 \mathrm{~mm}$, 測定ポイント数は14000ポイントである。なお, シートは歩行情報を分析するノートパソコンと接続し ている。

歩行開始時の加速と終了時の減速を考慮して, 歩行 路の中央に $2.4 \mathrm{~m}$ の測定シートを設置し, その前後 2 $\mathrm{m}$ をインターバルとする計 $6.4 \mathrm{~m}$ を歩行区間とした。 解析には， $2.4 \mathrm{~m}$ の測定シート上を歩いた際の歩行速 
度を用いた。測定条件は裸足で，まず「普段歩いてい るように歩いてください」と口頭指示を行い, 通常歩 行速度で 2 回測定して平均值を算出した。その後, 最 速歩行は「できる限り速く歩いてください。ただし走っ てはいけません」，低速歩行は「できるだけゆっくり 歩いてください。ただし立ち止まってはいけません」 と口頭で指示し, 通常歩行と同様 2 回測定してその平 均值を求めた。最速歩行と低速歩行の測定順はランダ ムとした。

身体組成の測定には，生体電気インピーダンス法に よるポータブル体成分分析装置 InBody430（インボ ディ・ジャパン製）を用いた。測定によって得られた 骨格筋量, 体脂肪量, 上肢筋量, 下肢筋量, 体幹筋量 を分析に用いた。立位バランステストとして, 開眼で の片脚立位時間，TUG，FRTを測定した。片脚立位 時間 ${ }^{14)}$ は 120 秒を上限として，ストップウォッチを用 いて左右 2 回ずつ行い, 左右の最長時間の平均值を代 表值として採用した。この際, 対象者は体側に上肢を つけ $2 \mathrm{~m}$ 先の印を注視するように指示し，上肢が体 幹を離れる，支持脚の位置がずれる，または対側の足 部が床につくまでの時間を測定した。

TUG の測定 ${ }^{15)}$ は，坐面の高さが $40 \mathrm{~cm}$ 肘掛けのな い椅子に腰掛けた姿勢から, 開始の合図で歩き出し 3 $\mathrm{m}$ 前方に配置したポールを回って着座するまでの時 間をデジタルストップウォッチで測定した。歩行の条 件は最速歩行 ${ }^{16}$ で行うように説明した。

FRTの計測17)には, リーチ測定器（OG 技研 GB210）を用いて測定した。対象者には, 裸足で肩幅に 開脚して立ち, 利き手の肘を伸展させ肩を $90^{\circ}$ 挙上位 にして踵を浮かせないこと, 体幹を回旋させないこと を指示した上で限界までの前方リーチを行わせた。そ の際の最大移動距離を測定したが，踵部が浮いた場合 やバランスを崩した場合は測定を中止し再度計測した。 なお，認知機能の評価には MMSE を用いた。MMSE
は，広く用いられる全般的な認知機能障害のスクリー ニング検查であり，11項目30点満点で評価される。測 定は対面式で行い，得られた合計点を解析に用いた。

統計処理は, 通常歩行速度 - 最速歩行速度 · 低速歩 行速度挹よび最速歩行と低速歩行の速度差と年齢 . MMSE - 身長 ·体重 $\cdot$ Body mass index (BMI), 身 体組成（骨格筋量 ·体脂肪量 - 上肢筋量 - 下肢筋量 体幹筋量)，各種立位バランステスト(片脚立位時間・ $\mathrm{TUG} \cdot \mathrm{FRT})$ との関連をピアソンの相関分析を用い て検討した。なお, 解析には統計解析ソフトSPSS21.0 （IBM 社製）を用い，有意水準は $5 \%$ とした。

\section{III. 結 果}

対象者14名の各歩行速度における歩行パラメータの 比較を表 1 に，その他の測定值を表 2 に示す。歩行速

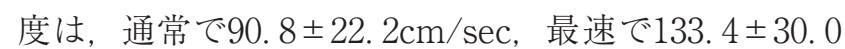
$\mathrm{cm} / \mathrm{sec}$, 低速で $47.2 \pm 16.4 \mathrm{~cm} / \mathrm{sec}$ であり, 有意差が 認められた。その他, 低速歩行時は通常・最速時と比 べて, ストライド長と歩幅は有意に狭く, 歩隔と歩行 角は有意に広がり，立脚時間と両脚支持時間は有意に 延長した。つま先角には有意差は認められなかった(表 1 )。

通常歩行速度と有意な相関を示したのは TUG $(r=$ $-0.721, \mathrm{p}<0.01)$ のみであり, 最速歩行速度のそ れは身長 $(r=0.631, p<0.05)$, TUG $(r=-0.875$, $\mathrm{p}<0.01), \operatorname{FRT}(\mathrm{r}=0.548, \mathrm{p}<0.05)$ の 3 項目であっ た。一方，低速歩行速度と有意な相関を示したのは骨 格筋量 $(r=-0.648, p<0.05)$, 上肢筋量 $(r=-0.574$, $\mathrm{p}<0.05)$ ，下肢筋量 $(r=-0.600, \mathrm{p}<0.05)$, 体幹 筋量 $(r=-0.550, p<0.05)$ の 4 項目であった。さ らに, 最速歩行と低速歩行の速度差と有意な相関を示 したのは身長 $(r=0.552, p<0.05)$, 骨格筋量 $(r=$ $0.736, p<0.01)$, 上肢筋量 $(r=0.627, p<0.05)$, 下肢筋量 $(r=0.787, p<0.01)$, 体幹筋量 $(r=0.675$,

表 1 各歩行速度における歩行パラメータの結果 $(\mathrm{n}=14)$

\begin{tabular}{lccccc}
\hline & 最速歩行 & 通常歩行 & 低速歩行 & $\mathrm{F}$ 值 & 多重比較 \\
\hline 歩行速度 $(\mathrm{cm} / \mathrm{sec})$ & $133.4 \pm 30.0$ & $90.8 \pm 22.2$ & $47.2 \pm 16.4$ & $91.3^{* *}$ & 最速 $>$ 通常 $>$ 低速 \\
ストライド長 $(\mathrm{cm})$ & $105.0 \pm 21.2$ & $91.7 \pm 20.5$ & $71.0 \pm 20.9$ & $32.6^{* *}$ & 最速 $>$ 通常 $>$ 低速 \\
歩幅 $(\mathrm{cm})$ & $53.2 \pm 6.5$ & $46.1 \pm 7.4$ & $36.4 \pm 8.0$ & $59.1^{* *}$ & 最速 $>$ 通常 $>$ 低速 \\
歩隔 $(\mathrm{cm})$ & $9.8 \pm 3.0$ & $10.3 \pm 3.3$ & $12.5 \pm 3.9$ & $14.9^{* *}$ & 最速 $\cdot$ 通常 $<$ 低速 \\
立脚時間 $(\mathrm{sec})$ & $0.5 \pm 0.1$ & $0.6 \pm 0.1$ & $1.1 \pm 0.3$ & $58.8^{* *}$ & 最速 $<$ 通常 $<$ 低速 \\
両脚支持時間 $(\mathrm{sec})$ & $0.1 \pm 0.0$ & $0.1 \pm 0.0$ & $0.3 \pm 0.1$ & $60.3^{* *}$ & 最速 ·通常 $<$ 低速 \\
歩行角 (度) & $11.1 \pm 4.6$ & $14.2 \pm 6.6$ & $20.8 \pm 9.8$ & $19.6^{* *}$ & 最速 · 通常 $<$ 低速 \\
つま先角 $($ 度 & $7.6 \pm 5.6$ & $7.2 \pm 6.0$ & $7.8 \pm 598$ & $0.7 \mathrm{~ns}$ & \\
\hline
\end{tabular}


表 2 歩行以外の測定結果 $(n=14)$

\begin{tabular}{|c|c|c|c|c|}
\hline & 平均值 & 標準偏差 & 最小值 & 最大值 \\
\hline 年齢（歳） & 71.3 & 6.1 & 64.0 & 85.0 \\
\hline MMSE（点） & 27.3 & 2.1 & 24.0 & 30.0 \\
\hline 身長 $(\mathrm{cm})$ & 155.9 & 8.3 & 137.0 & 169.0 \\
\hline 体重（kg） & 57.6 & 7.6 & 45.5 & 71.4 \\
\hline BMI & 23.7 & 2.8 & 18.2 & 27.9 \\
\hline 骨格筋量（kg） & 22.4 & 4.5 & 17. 0 & 28.9 \\
\hline 体脂肪量（kg） & 16. 0 & 5.3 & 9.2 & 26.7 \\
\hline 上肢筋量 $(\mathrm{kg})$ & 4.3 & 1.2 & 3.0 & 6.5 \\
\hline 下肢筋量（kg） & 12.2 & 2.7 & 8.5 & 16.5 \\
\hline 体幹筋量（kg） & 18. 2 & 3.5 & 13. 2 & 24.6 \\
\hline 片脚立位時間（sec） & 16.9 & 17.8 & 1.8 & 53.0 \\
\hline TUG（sec） & 10.2 & 5.4 & 6.7 & 27.4 \\
\hline FRT $(\mathrm{cm})$ & 21.3 & 5.7 & 11.5 & 29.9 \\
\hline
\end{tabular}

MMSE: Mini-mental state examination

BMI: Body mass index

TUG: Timed up \& go test

FRT: Functional reach test

表 3 各歩行速度別相関分析の結果 $(\mathrm{n}=14)$

\begin{tabular}{|c|c|c|c|c|}
\hline & 歩行速度（通常） & 歩行速度（最速） & 歩行速度（低速） & 最速歩行一低速歩行 \\
\hline 年齢 & -0.335 & -0.394 & -0.173 & -0.286 \\
\hline MMSE & 0.460 & 0.150 & 0.169 & 0.055 \\
\hline 身長 & 0.244 & $0.631^{*}$ & -0.355 & $0.552^{*}$ \\
\hline 体重 & 0.012 & 0.367 & -0.305 & 0.509 \\
\hline BMI & -0.184 & -0.146 & 0.004 & -0.141 \\
\hline 骨格筋量 & -0.078 & 0.417 & $-0.648^{*}$ & $0.736^{* *}$ \\
\hline 体脂肪量 & 0.142 & -0.020 & 0.486 & -0.273 \\
\hline 上肢筋量 & -0.182 & 0.344 & $-0.574^{*}$ & $0.627^{*}$ \\
\hline 下肢筋量 & 0.070 & 0.497 & $-0.600^{*}$ & $0.787^{* *}$ \\
\hline 体幹筋量 & -0.090 & 0.420 & $-0.550^{*}$ & $0.675^{* *}$ \\
\hline 片脚立位時間 & -0.008 & 0.152 & -0.153 & 0.225 \\
\hline TUG & $-0.721^{* *}$ & $-0.875^{* *}$ & -0.264 & $-0.698^{* *}$ \\
\hline FRT & 0.418 & $0.548^{*}$ & -0.055 & $0.551^{*}$ \\
\hline
\end{tabular}

$\mathrm{p}<0.01), \quad$ TUG $(\mathrm{r}=-0.698, \mathrm{p}<0.01)$, FRT $(\mathrm{r}=$ $0.551, \mathrm{p}<0.05 ）$ の 7 項目であった（表 3 ）。

\section{IV. 考 察}

先行研究におけるパーキンソン病患者の歩行速度は, 通常歩行で $94 \mathrm{~cm} / \mathrm{sec}^{9)}$ P $85 \mathrm{~cm} / \mathrm{sec}^{12)}$, 最速歩行で 132 $\mathrm{cm} / \mathrm{sec}^{10)}$ ，低速歩行で $49 \mathrm{~cm} / \mathrm{sec}^{12)}$ と報告されている。 本研究における対象者の歩行速度は, 通常歩行が平均 $90.8 \mathrm{~cm} / \mathrm{sec}$, 最速歩行が $133.4 \mathrm{~cm} / \mathrm{sec}$, 低速歩行が
47.2 cm/secであり, 先行研究と近似した結果を示し たことから，本研究対象者が指示通りに歩行速度を変 化させることができたものと推察した。なお，低速歩 行時の歩行の特徵として, ストライド長や歩幅を狭く し，立脚時間と両脚支持時間を延長させて速度を遅く していることが確認された。また，歩隔と歩行角が広 がるのは，低速での歩行には立位バランスが要求され るためと推察した。

通常歩行速度および最速歩行速度は, ともに TUG 
と有意な負の相関を示した。TUGは，高齢者のバラ ンス機能の評価法として開発15)され，その信頼性と妥 当性が繰り返し報告されている 片道 $3 \mathrm{~m}$ 往復 $6 \mathrm{~m}$ の歩行を行うことから, 歩行能力 の指標とされることもあり ${ }^{18)}$, 歩行速度と高い相関を 示した本研究結果も矛盾しない。また, 最速歩行速度 は身長と FRT とも有意な相関が認められた。すなわ ち, 最速歩行が速い者ほど身長が高く，前方へのバラ ンス機能が高いことが示された。最速歩行速度と身長 との関連については既に明らかにされており ${ }^{19}$, パー キンソン病患者においても, 最速歩行速度を検討する 場合は身長で補正する必要性が示唆された。Sawada $ら^{11}$ は, パーキンソン病患者の最速歩行速度と TUG やFRTなどのバランステストとの間に，高い相関が 認められたと報告している。本研究結果もSawada ら の結果を追認し, 最速歩行速度はパーキンソン病患者 のバランス機能をよく反映する歩行評価法であること が確認された。

一方, 低速歩行速度は骨格筋量や上肢 - 下肢 - 体幹 の筋量と有意な中等度から高い相関が涊められた。八 谷ら ${ }^{12}$ の研究では, パーキンソン病患者の低速歩行速 度と下肢筋力である足趾把持力との間に有意な相関が 認められ，下肢筋力が強い患者ほどより低速で歩行で きると報告している。本研究結果も先行研究と矛盾し ない結果であった。さらに, 最速歩行と低速歩行の速 度差を用いて相関分析を行うと, 最速歩行と低速歩行 の速度とそれぞれに有意な相関を示したすべての項目 と有意な相関が認められた。すなわち, 速度差が大き い患者ほど上肢・下肢・体幹すべての骨格筋量が多く， TUG P FRT で測定したバランス機能が良好である ことが示された。パーキンソン病患者は, 疾患特有の 安静時振戦, 無動・寡動, 筋固縮, 姿勢反射障害など

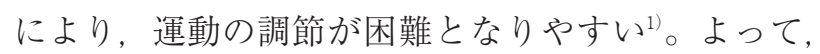
パーキンソン病患者は意図的に歩行速度を速めたり， 遅くできることが彼らの身体機能を反映するものと推 察した。

これらの知見から，パーキンソン病患者の歩行能力 評価は通常歩行で速度計測するよりも，最速歩行に加 えて低速歩行でも評価する重要性が示された。歩行速 度の計測は, 専用の測定機器を必要とせず, ストップ ウォッチで計測できる最も一般的な定量的歩行能力評 価として普及している。今回の結果は, パーキンソン 病患者に対する地域リハビリテーション活動の効果判 定を行う上で臨床的意義が高い。
ただし，本研究で対象としたパーキンソン病患者は 十分な投薬管理が行えており, 内服薬の効果のある才 ン時間带にすべての測定を実施した。よって本研究結 果は，パーキンソン病患者特有のすくみ足や小刻み歩 行, 突進現象などの歩行障害 ${ }^{20}$ が出現していない状態 に限定される。今後は，長期的な視点で検討する必要 がある。

\section{引用文献}

1）菊地誠志：Parkinson 病の運動症状と精神症状. 神経治 療, 2017, 34(3) : 195-198.

2）山永裕明，野尻晋一：図説パーキンソン病の理解とリハ ビリテーション．三輪書店，東京，2010，2-5

3）水野美邦, 近藤智善：よくわかるパーキンソン病のす心゙ て. 永井書店, 東京, 2004, 207-215.

4）中島雪彦, 三穂野大樹, 前田悠希・他：パーキンソン病 患者の在宅生活支援． OT ジャーナル，2013，47(6)：527 -530 .

5) Lauhoff P, Murphy N, Doherty C, et al: A controlled clinical trial investigating the effects of cycle ergometry training on exercise tolerance, balance and quality of life in patients with Parkinson's disease. Disabil Rehabil, 2013, 35(5): 382387.

6) Brusse KJ, Zimdars S, Zalewski KR, et al: Testing functional performance in people with Parkinson disease. Phys Ther, 2005, 85(2): 134-141.

7）内藤 寞：歩行と姿勢（重心動摇）一すく久足と重心移動 障害. Brain Med, 2007, 19(4)：359-367.

8) Okuda S, Takano S, Ueno M, et al: Gait analysis of patients with Parkinson's disease using a portable triaxial accelerometer. Neurology and Clinical Neuroscience, 2016, 4(3): 9397.

9) Paker N, Bugdayci D, Goksenoglu G, et al: Gait speed and related factors in Parkinson's disease. Journal of Physical Therapy Science, 2015, 27(12): 3675-679.

10）八谷瑞紀, 村田 伸, 熊野 亘・他：パーキンソン病患者 に扔ける虚弱高齢者用10秒椅子立ち上がりテスト（Frail CS-10）の有用性. 理学療法科学, 2012, 27(4)：391-395.

11) Sawada M, Murakami T, Morioka S, et al: Relationship between gait cycle variation on 10-m walk and motor function in parkinsonian patients. 鳥取臨床科学研究会誌, 2015, 6 (1) : 29-34.

12）八谷瑞紀, 村田 伸, 熊野 亘・他：パーキンソン病患者 に扔ける低速歩行と足趾把持力との関連. ヘルスプロモー ション理学療法研究, 2013, 3(2)：53-57.

13) Chang JS, Kim TH, Kim Het, al: Qualitative muscle mass index as a predictor of skeletal muscle function deficit in Asian older adults. Geriatrics \& Gerontology International, 2017 17(1): 99-107.

14）文部科学省：新体力テスト実施要項 (65 79歳対象). http: //www.mext.go.jp/a_menu/sports/stamina/03040901.htm （閲覽日2018年 5 月 7 日） 
15) Podsiadlo D, Richardson S: The timed "Up \& Go": a test of basic functional mobility for frail elderly persons. J Am Geriatr Soc, 1991, 39(2): 142-148.

16）島田裕之, 古名丈人, 大渕修一・他：高齢者を対象とした 地域保健活動における Timed Up \& Go Testの有用性. 理 学療法学, 2006, 33(3) : 105-111.

17) Duncan PW, Weiner DK, Chandler J, et al: Functional Reach: A New Clinical Measure of Balance. Journal of Gerontology, 1990, 45(6): M 192-197.

18）村田 伸, 大田尾 浩, 村田 潤 - 他：虚弱高齢者に扔け る Timed Up and Go Test, 歩行速度, 下肢機能との関連. 理学療法科学, 2010, 25(4) : 513-516.

19）大杉紘德, 村田 伸, 堀江 淳 - 他 : 地域在住高齢者の各 種歩行パラメータに関連する要因分析. ヘルスプロモー ション理学療法研究, 2014, 4 (1) : 31-35.

20）中島 孝：歩行訓練のエビデンスーパーキンソン病. 総 合リハビリテーション, 2017, 45(3)：201-207. 